\title{
The Third Space Formation of Hindu In Sidoarjo
}

\author{
Siti Alif Ulfah \\ alif.ulfa53@gmail.com
}

\begin{abstract}
This article discusses the formation of a 'third space' and the articulation of Hindu cultural identity in Sidoarjo, East Java. The hegemonic discourse generally places restrictions on the articulation of religion and related issues. Notwithstanding, minority groups have tried to maintain and represent their Hindu identity. This paper addresses this issue through ethnographic research, adopting a post-colonial perspective, drawing particularly on Homi K. Bhabha's theory of the third space (space in between). The results showed that Hindus have interpreted and articulated their cultural space through identity negotiation. In the Sidoarjo regency, there are three primary categories of Hinduism: Hinduism from Sidoarjo; Hinduism from outside Sidoarjo; and Hinduism from Bali. Despite differences between them, Hindus have worked together to develop strategies to challenge the hegemonic discourse, developing a third spatial formation that is shaped by cultural codes, social networks, educational institutions, military structure, and ogoh-ogoh. As such, the Hindus third space is productive, dynamic, and negotiatiable.
\end{abstract}

Keywords: Hindu community, postcolonial identity, third space

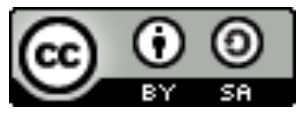

Copyright $\odot 2021$ by Author(s)

This work is licensed under a Creative Commons Attribution-ShareAlike 4.0 International License. All writings published in this journal are personal views of the authors and do not represent the views of this journal and the author's affiliated institutions.

\section{HOW TO CITE:}

Ulfah, Siti Alif. "The Third Space Formation of Hindu in Sidoarjo"(2021) 1:2 Contemporary Sociological Issues $110-123$.

Submitted :November 25, 2020

Revised :June 14, 2021
Accepted

Publish
:July 25, 2021

: August 31, 2021 


\section{INTRODUCTION}

This research begins by discussing the demolition of the statue in the Sidoarjo square related to the city icon promoted by the local government. In 2015, a number of Islamic organizations protested the establishment of the Jayandaru Monument and took down nine statues that represented the various occupations of the Sidoarjo community. The construction of the Jayandaru monument was initiated by a company in the seafood trade in Sidoarjo. The statues construction was controversial, violating Sidoarjo's Islamic values and cultural traditions that prohibit representation of the human form ${ }^{1}$. The square is a public space where people engage in demonstrations to voice their interests, aspirations, and opinions. As such, the destruction of these statues represented the state legitimizing its power and how the local community negotiated state power.

The figuration of the demolition of the statue in the plaza had three major characteristics. First, the residents and banser who protested for the demolition of the statue on the basis that it violated Islamic sharia. The protestors demonstrated the strength of the masses, dominating social spaces in the name of Islam. Second, regional government responsible for local policies including developing the image and culture of Sidoarjo through the statue. As a representation of the state and apparatus that should be able to manage plurality, it is 'challenged' by the dominant power. Third, the Balinese artists work reflected Hindu traditions attached to their profession, marking them as a marginal group. This presents an interesting case through which to explore artistic articulations outside the dominant group.

To understand the significance of these events it is crucial to acknowledge the identity struggles experienced by Hindus as a minority, immigrant group in Sidoarjo. The number of officially recorded Parisada Hindu Darma Indonesia (PHDI) in Sidoarjo is 450 families spread across 12 sectors in several sub-districts (according to the Chairman of PHDI Sidoarjo, 2017). The Sidoarjo Hindu community strengthens their identity through institutions within the PHDI. The PHDI was initiated by the government to forge synergies between Hindus across the country.

Hindus built a temple as a place of worship (function of religiosity) to Sang Hyang Widhi (God Almighty). Geertz ${ }^{2}$ discusses the various functions of temples which are closely related to Hindu religious practices. Temples in Sidoarjo are spread across 3 locations: Nirwala Jati Temple in Sekelor, Balongbendo District; Margo Wening Temple in Balonggarut Village, Krembung District; and Jala Sidhi Amarta Temple in the Juanda Navy cluster area.

Hindus have historical roots in Sidoarjo but are not fully considered to be present. Hindu heritage in Sidoarjo can traced back to the remains of artifacts and representations of temples. Sidoarjo is not exclusively understood through a singular religious narrative. As such, it is important to explore the Hindu narrative on the one hand, and how it has become part of cultural articulation on the other hand.

1 See more: https:/www.merdeka.com/peristiwa/bentuk-manusia-sempurna-monumen-jayandarusidoarjo-dianggap-berhala.html [Accessed on 24 November 2016 at 16.15 WIB.]

${ }^{2}$ Clifford Geertz, Tafsir Kebudayaan (Yogyakarta: Kanisius, 1992). 
To emphasize the problematic identity of Hindus in Sidoarjo's hegemonic discourse, this paper draws on Bhabha's work which articulates the importance of identity identity. ${ }^{3}$ Bhabha refers to "the third space in the "other," meaning that there is a space for dialogue between minority groups and the dominant power. "The other" represents the position of the minority. Thus, there is hybridity space among the dominant discourse.

The concept of hybridization is defined as a form of subjectivity of colonial subjects. Drawing on the knowledge systems that define their social position, subjects are positioned within social spaces to be aware of themselves, their past, who controls them. From this existing consciousness, the subject creates practices that differentiate themselves from the systems that govern them, establishing a rift in the unity of the ruling knowledge system. ${ }^{4}$ Subject's identity within dominant spaces are never fixed; they continually engage in complex processes of representation and negotiation to establish a hybrid identity. In this sense, Bhabha's point his affirmation of the meaning of postcolonial identity identity. ${ }^{5}$

Hindu habitation in Sidoarjo is complex and diverse. They engage in continuous negotiation between their identity and the subjects of the dominant cultural traditions and identities. Sidoarjo's dominant cultural space is a dynamic and diverse sphere in an industrial setting. As such, this research defines the critical problem of the formation of a third space of Hindu identity in Sidoarjo. In post-colonial studies, especially the works of Homi K. Bhabha, the 'third space' refers to that of dominant groups trying to control and monopolize various forms of cultural articulation. However, spaces between minority groups are formed in various ways, particularly when minorities present complex characteristics that exist in certain social categories.

This research paper uses a qualitative ethnographic approach. The ethnographic approach is intended to describe certain groups, ethnicity, race, identity, etc. "Describing," according to Atkinson ${ }^{6}$, refers to a researchers use of their sensory abilities and theoretical analysis skills to explore phenomena. This study adopted a postcolonial perspective which is translated as unresolved problems upon the state and colonialism. Data collection was carried out through observation, interviews, and documentations. The researcher aimed to describe the formation of Hindu identity in Sidoarjo who continue to engage in cultural negotiation.

\section{CULTURAL ENCOUNTERS: HINDU IDENTITY IN HISTORICAL NARRATIVE}

\footnotetext{
${ }^{3}$ Richard King, Agama, Orientalisme, dan Poskolonialisme (Yogyakarta: Qalam, 2001).

${ }^{4}$ Hery Prasetyo, Development And Uneven Development (Does Democratization Work?) (2012).

${ }^{5}$ Martin Lukitto Sinaga, IdentitasPoskolonial "Gereja Suku” dalam Masyarakat Sipil (Yogyakarta: LkiS, 2004).

${ }^{6}$ Martin Hammersley \& Paul Atkinson, Ethnography Principles in Practice, third ed (New York: Taylor \& Francis e-Library, 2007).
} 
Next to the veranda of the madya temple (the centre of the temple), in the midst of busy preparations for the Tawur Agung Kasanga (the ceremony before Nyepi), four people gathered to chat with one another. One of them is named Pak Ketut. The researcher had previously asked Mr. Ketut for permission to participate in a series of ceremonies. At the beginning of the interview, the researcher shook hands with Pak Ketut and the other participants in sequence. The last hand shake was with a man who had a stern gaze and shocking tone, who smiled and said "Can you shake hands?"

People's responses to the anticipation of a handshake can help determine potential limitations that may guide the following interaction. This reflects the way the subjects relate to the act of shaking hands and may determine their openness to engaging in the following discussion. He and them as Hindu subjects. As for me, the researcher, as a subject who happened to be represented by the researcher as what is called an Islamic idea and entity. Islamic entity refers to the attributes of the clothes and veils worn by participants. The researcher's visual preference determines how a question should be asked. The subject who questioned the cultural norms that limit Muslim women's behaviours when she shook her hand.

The meeting on Monday morning reminded me of a time when the researcher visited Pak Nyoman's house some time before regarding the research permit. From the front, the house stands out from the rest, it has a gate flanked by two statues. The pathway to the main door is decorated with inscence sticks and flower offerings with a small carved stone building on the right hand side.

Upon their first meeting the researcher was distracted by Pak Nyoman's clothing. He was wearing a senteng, a piece of cloth tied around the waist with a motif sarong and a bracelet made of red, white, and black thread wrapped around his hand. After a while, Pak Nyoman rose to his feet to get an udeng to wear. He demonstrates the details of his clothing attributed to Hindu prayers, demonstrating his position as the chairman of Parisadha Hindu Dharma Indonesia (PHDI) in Sidoarjo.

During both encounters, the openness of persons to engage in a hand shake and the presence of clothing symbols that indicate a Hindu faith are key points of analysis. When meeting people with different cultural identities, it is important for Hindu's to communicate their identity.

Certain utterances and physical attributes, including clothing, have become important indicators of a person's identity and can be a critical entry point to communication. For researchers this becomes part of a discursive narrative between different entities and can influence people's awareness of, and interaction with, Hindu identities.

Interactions between entities with different identities can be interpreted in line with Bhabha's postcolonial portrait of the self and the other. Bhabha emphasizes that the question of identity is represented through various readings of the self and the other. In a postcolonial perspective 'the other' has become an entirely different issue of emergence because it rejects the homogeneous domination. ${ }^{7}$

\footnotetext{
${ }^{7}$ Martin Lukitto Sinaga, supra note 5.
} 
According to Bhabha ${ }^{8}$, a process of self-reflection and representation occurs when two entities meet. In the encounter described above, the Hindu subject translates his identity through the concept of the self, relating to cultural experiences and situations. The other is represented through a reading of who the other is in the same space setting.

Colonial perspectives interpret and articulate the subject through specific cultural signs, labelling them as the other. As such, the encounter with the Hindu subject above can be considered as a colonial interaction. These interpretations of the other form stereotypes attached to different identities, marking differences and reinforcing the status of the other. ${ }^{9}$

Postcolonial analyses of Hindu identity begins in a spatial setting where two entities meet. This may be in a Hindu's house or elsewhere in Sidoarjo. Hindu heritage in Sidoarjo is an important indicator of how Hinduism helped shape the Sidoarjo region. In the book, the Hindu narrative clearly explains how during the period of the Jenggala kingdom to the territorial rule by the Dutch.

Based on the Sidoarjo History Tracing Team ${ }^{10}$, the kingdom era lasted from 1019 to 1042. Sidoarjo is the territory of the Kahuripan kingdom led by a king named Airlangga (son of Udayana), one of the kingdoms in Bali from Empress Mahendratta. Another indicator of Hindu history in Sidoarjo is the finding of a Kamalagyan inscription. In Siswantoll, the word kalagyan in the Kamalagyan inscription refers to the name of a village. Kamalagyan is identified as Klagen Village, which is now in Sidoarjo Regency.

In this narrative of Hindu history, Erlangga and the Jenggala kingdom he ruled became a central point of the Sidoarjo region's existence. Meanwhile, there is evidence of inscriptions in several areas of Sidoarjo indicating its Hindu heritage. However, the historical record keeping does not further investigate the historical Hindu narrative in Sidoarjo.

During the colonial period, the Dutch East Indies tried to control the Sidoarjo regency and separate it from Surabaya. The Government Decision Number: 9/1859 dated January 31, 1859 under the name Sidokare Regency marks the day Sidoarjo become a city. The name Sidokare was considered to carry bad connotations and the Sidokare Regency was renamed the Sidoarjo Regency as per the Dutch East Indies Government No. 10/1859 dated 28 May Staatsblad No. 32, the name of Sidokare Regency was changed to the name of Sidoarjo Regency. ${ }^{12}$

There has been a leap in the production of knowledge of Hindu identity in Sidoarjo, especially in terms of the welfare of Hindu entities. Prior to the colonial period, Hindu narratives and their cultural origins had taken root. When the Dutch East Indies tried to

${ }^{8}$ Homi K Bhabha, The Location of Culture (London: Rouledge, 1994).

${ }^{9} \mathrm{Ibid}$ at $95-96$.

${ }^{10}$ Tim Penelusuran Sejarah Sidoarjo, Jejak Sidoarjo dari Jenggala ke Suriname (Sidoarjo: Ikatan Alumni Pramong Praja Sidoarjo, 2006).

${ }^{11}$ Siswanto, "Identifikasi penggunaan Lahan Berdasarkan Sumber Prasasti Abad Ke-ll Masehi di Jawa Timur" (2015) Purbawidya: Jurnal Penelitian dan Pengembangan Arkeologi.

12 Selayang pandang kabupaten Sidoarjo, 2018: Dinas Komunikasi dan Informatika Sidoarjo. http://portal.sidoarjokab.go.id/uploads/2018/07/selayangpandang2018revisi.pdf [accessed on 24 October 2018] 
dominate the Sidoarjo region, these historical roots were broken, though their relics remain in several areas of Sidoarjo as evidence of Hindu history in the area.

Hindus are now a minority in the spatial setting of Sidoarjo. It is important to discuss the turmoil of Hindu identity relates to Sidoarjo city. In the struggle to reestablish Hindu identity in Sidoarjo, the Sidoarjo Hindu community embarked on a journey to build a temple as a place of worship and acceptance of identity.

The plan to build a temple in Balonggarut village, Krembung district was rejected by local residents. To obtain legal permission to establish a place of worship Hindus in Sidoarjo applied to the Sidoarjo Regency Government in 1971 for a permit to establish a temple. Hindu named Pak Untung donated land upon which the temple could be built.

In accordance with Pancasila and the 1945 Constitution every community should be free, safe, and comfortable to worship. Notwithstanding, at the local community and village apparatus level, the existence of alternative religions continues to be rejected, experiencing threats and destruction of places of worship. Permits to establish places of worship are regulated by the Joint Decree of the Minister of Religion and the Minister of Home Affairs No. 10 of 1969. This contains the government's duties of implementation to ensure the smooth development of places of worship and religion. This regulation was revised regarding the procedure for the construction of places of worship and was later regulated by the Joint Regulation of the Minister of Religion and the Minister of Home Affairs No. 9 and No. 8 of 2006.13

In 1976, proposals to build the temple continued to be rejected and no permit was granted. In 1981 a group of Hindus including Pak Wirai approached the Sidoarjo district court and police chief, facilitating the temple's licencing, funding, and permits. On January 1, 1992, a temple was inaugurated by the Regent of Sidoarjo, Edhi Sanyoto, and was officially named Pura Tirto Wening.

Later, land was purchased to facilitate the extension of the temple on the left. In 2002 the Penataran Agung Margo Wening temple was built; tirto means water, while wening means clear, and margo means road. The process of relocating the Penataran Agung Margo Wening temple took two years. The old temple, Tirto Wening temple, is still used by Pak Untung's family to pray, serving as a reminder of their role in establishing the temple. This temple, among others, is a key site of collective memory regarding the struggle for establishing Hindu spaces of worship in Sidoarjo.

The Margo Wening temple has become a critical starting point for the articulation of Hindu identity in Sidoarjo because of the controversial process prohibiting the establishment of a temple in the village environment. The polemic against establishing places of worship articulated the unaccommodating religious sentiment of the time. Pura Margo Wening has long a history of identity struggles with long and complicated licensing processes, eventually leading to the inauguration of the Sidoarjo Regent. Pura Margo Wening was the first temple in Sidoarjo and is a pioneer for the establishment of other places of worship in Sidoarjo.

${ }^{13}$ https://tirto.id/syarat-syarat-mendirikan-rumah-ibadah-masjid-hingga-gereja-eotQ [diakses pada 10 maret 2020] 
These historical struggles surrounding the articulation of Hindu identity in Sidoarjo contribute to the development of an awareness of the Hindu subject. The struggle, and the collective, cultural memories of this, can be interpreted as an affirmation of identity. The place of worship acts as a witness to these events, rooted in the selfhood of the Hindu subject. Hindu identity is build through the history of this temple and determines how Hindus see other entities in Sidoarjo. Hindu religiosity is not equal to its role in the dominant historical narrative of Sidoarjo. This disjuncture indicated that Hindus were trying to articulate and establish their identity, which was not initially supported or protected by the Sidoarjo regency government.

Official government policy and historical narratives in Sidoarjo have generally excluded Hindu perspectives and experiences. This exclusion makes it difficult for Hindus to articulate their identity in a context that fails to recognise their history. In this sense, we can understand Bhabha's conceptualisation of postcolonial identity through reading how otherness is linked to territorial control. Hindu identity contains an inherent awareness of others in the spatial setting of Sidoarjo. As such, the image of autonomous space in Sidoarjo seems encompass the Hindu discourse itself. The dynamics of Hindu identity are intimately linked to the appearance of Sidoarjo.

The practice of seeking and translating cultural identities fails to acknowledge Hindus historical presence in Sidoarjo. The discourse that appears is in the form of Hindu artifacts, relics of Hindu statues and inscriptions packaged as royal history. Some Hindus are challenging the state-legitimised discourse and are fighting for their own history and Sidoarjo identity, acknowledging the role of the Hindu subject. When encountering people outside Hinduism, his expression shows that there is a lingering wound in the hearts of the Sidoarjo Hindus related to the struggle for temple construction and Hindu resistance at that time.

Sidoarjo's anniversary is not considered a part of Hindu identity. There are no cultural rituals or festivals intended specifically to commemorate the role of Hinduism in Sidoarjo's history and identity. This celebration appears to exist separately from the identity of the Hindu community. History, or historicity, and cultural syncretism is not fully appreciated in this research without acknowledging this history. Islamic culture remains a narrative focal point, while Hindu cultural codes are not used in other communities.

\section{HINDU SUBJECTIVITY IN SIDOARJO}

In Sidoarjo, Hindu identity is no longer a singular, it has become more fluid and diversified as with changing dynamics and subjects. Based on data in the field, Hindu identities can be divided into three categories: Hinduism from Sidoarjo; Hinduism from outside Sidoarjo; and Hinduism from Bali. Interaction between these forms has led to a collaborative, unifying Hindu identity. The Hindu subject articulates themself in different ways. Before the transmigration flow, the narrative of Hindus originally from the village of Balong Garut, Krembung district and the Sekelor area was tied to evidence 
of the historical existence of the Margo Wening temple, as described in the previous section.

Immigrants from Bali claim that the original Balinese Hindu is Bali Aga. Bali Aga comes from Old Javanese aga, meaning "mountains," serving as a reasonable and unresponsive description of a population whose main residence is a vast mountainous area that stretches out into the depths of the hilly island of Bali. ${ }^{14}$

Reuter ${ }^{15}$ argues that the Balinese Aga interpret their world and the structure of their relationships, both in banua and in other environments of social interaction, using the principle of "precedence". Precedency is used by individuals and groups in Bali to establish, affirm, and compete their status. Just as the status of Bali Aga in Balinese society centres on the conceptual differences between the 'newer' arrivals and the 'original' Balinese Aga who preceded them, so too is the situation with their own internal relations conceptualized by distinguishing between "predecessors" and "heirs".

According to Picard ${ }^{16}$, royal chronicles reported that Bali was conquered by the Majapahit royal army from Java in the $14^{\text {th }}$ century. They later founded the palace at Gelgel in the southeast of the island. After Majapahit fell in the early $16^{\text {th }}$ century, there are reports of a mass wave of immigration to Bali, including priests, writers, and artists, to combat the increasing pressure of Islam on the island of Java. Meanwhile, the Hindu Majapahit heritage was brought to the Gelgel palace, marking the emergence of what was later considered the golden age of Bali. Both Reuters and Picard, highlight the migration from Java to Bali and the complexities between immigrant and local cultures and identity.

Temple building has become a form of collaboration between Hindus in Sidoarjo. The Margo Wening temple is the product of collaboration between two cultural architectures - Java in the Bentar temple and Bali in its carvings. Hindus in Sidoarjo agree that the temple belongs together and are to be used for prayer and social activities. The unique characteristics of the temple building represent its strength and the reproduction of Hindu identity through places of worship. Discursive practices relating to one's identity operate through networks of power dynamics within the dominant discourse. ${ }^{17}$ This network was initially formed at the Margo Wening temple, Krembung, although many Hindus felt that they continued to be scattered across Sidoarjo and began to form small groups in residential zones.

These groups have now spread to 12 zones and is called a sector. However, according to the Parisadha regulations, they should be referred to as sub-districts. The Sidoarjo regency consists of 12 sectors: Deltasari; Tamansari; Waru; Tropodo; Juanda; Gedangan; City; Temple; Tanggulangin; Krembung; Trosobo; and Sekelor's newest sector (figure 1 ).

\footnotetext{
14 Thomas A Reuters, Custodians of The Sacred Mountains: Budaya dan Masyarakat di Pegunungan Bali (Jakarta: Yayasan Obor Indonesia, 2005).

${ }^{15}$ Ibid.

${ }^{16}$ Michel Picard, Bali: Pariwisata Budaya dan Budaya Pariwisata (Jakarta: kepustakaan Populer Gramedia, 2006).

${ }^{17}$ M Foucault, Arkeologi Pengetahuan (Yogyakarta: IRCiSoD, 2012).
} 


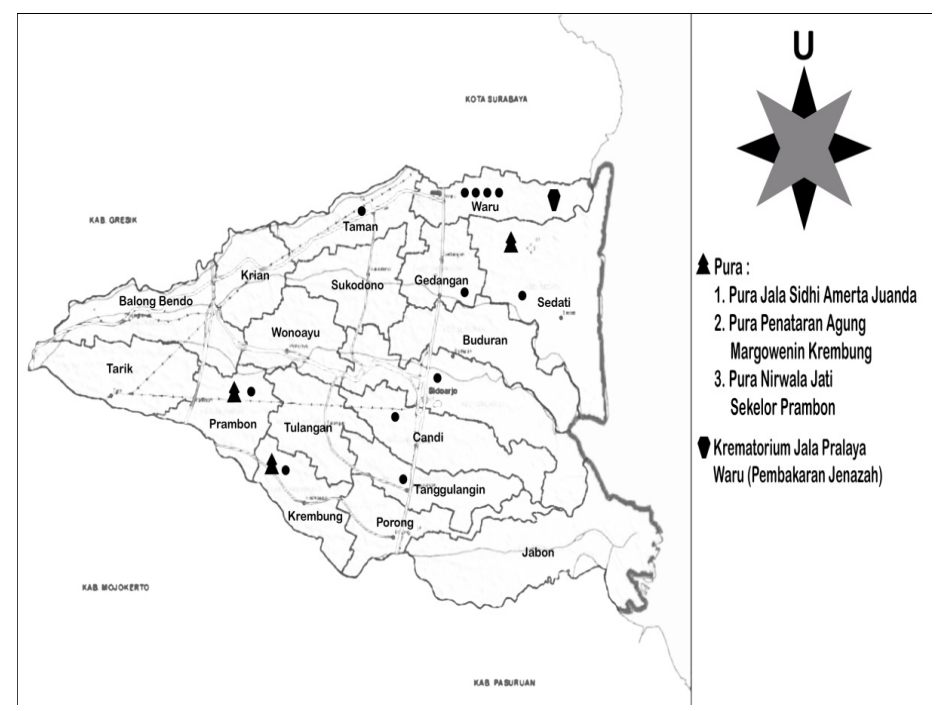

Figure 1. Distribution of 12 Hindu Sectors in Sidoarjo

In terms of distribution and quantity, Waru has the largest 4 sectors, including: the Deltasari sector, the Tamansari sector, the waru sector, and the Tropodo sector. These 4 sectors are located close to the city of Surabaya. In Figure 1., the distribution of the 12 sectors appears to be uneven in various sub-districts in Sidoarjo. The largest sector is in the northern region. Each of the three temples in Sidoarjo are located in respective sectors, in Sekelor, Krembung, and Juanda (TNI AL complex) the rest occupy the city centre. The number of sectors can increase according to the distribution of the residences of Sidoarjo Hindus.

Remarkably, this affirmation of identity does not characterize a conflict between Javanese or Balinese Hinduism, but rather, a form of solidarity. They consider themselves united in the religious sentiment of Hinduism, reinforcing the importance of internal networking. Social activities are not only centred in temples, but based on mutual agreement can be in Hindu residences. In this sense, they are no longer single, they have become diverse. Although limited by geographical and administrative boundaries, Hindu minority groups in Sidoarjo are mutually reinforcing, connecting social networks, and building communal ties. The division of 12 sectors in Sidoarjo is a strategic way of dividing territories, similar to a systematic and structured military. Further, the militaristic concept is relevant due to the use of military bases as places of worship (TNI AL complex), some Hindus are military personnel, and a military surveillance system.

\section{THE THIRD SPACE FORMATION OF HINDU IDENTITY}

This part focuses on the formation of marginal and intermediate Hindu subjectivities which operate in the third space. This third space shows the creative power of the Sidoarjo Hindu community in carving out space for their socio-cultural within the 
dominant space. The conception of "diversity in diversity," can be translated in numerous ways including: "different but one thing" and "divide it, but one thing too. ${ }^{18}$

\section{A. Formation through Cultural Codes and Social Networks}

Over time, Hindus have moved around Sidoarjo, interacting and bonding with residents. One of the key moments of social and cultural interaction is the Islamic Walima ceremony, also referred to as kenduren or selametan in Sidoarjo. This ceremony celebrates the community, usually commemorating births, weddings, or death.

Walima is a Javanese religious system. According to Geertz ${ }^{19}$ Slametan is the Javanese version of what is perhaps the most common religious ceremony in the world, the communal feast. Equal in almost all places, it symbolizes the mystical and social unity of those who participate in it. Handai taulan, neighbors, coworkers, relatives, local spirits, dead ancestors, and almost forgotten gods all sit together, bound in social groups, vowing to help and cooperate.

Geertz's findings ${ }^{20}$ show that the slametan in some Modjokuto communities is one of the abangan groups' media in expressing their religious face in basic and complex variations. This differs from the data found by Beatty ${ }^{21}$, who states that a slametan is a meal ceremony consisting of offerings, symbolic food, official greetings, and prayers. Participants see it as an integral part of their lives as social beings and understanding of themselves as Javanese; it encompasses local traditions. Beatty's findings ${ }^{22}$ show that, in the Bayu community, slametan is considered a rite, but there is a multiplicity of views held by individual participants. Beatty's criticism of Geertz was that the slametan was attended by 3 groups, not exclusively the abangan group. Selametan is a forum for shared accommodation, and acceptance of each other's differences.

The involvement of the subject in the social interaction platform through walima also offends the Nahdlatul Ulama (NU) and the Cak Nun figure. Nahdlatul Ulama (NU) and Cak Nun are cultural discourses that are considered to accept pluralist space. He built awareness by looking for a Hindu space with Islam. This can be interpreted as a strategy to build space by creating power in awareness (knowledge). The issue of belief is not necessarily debated, but can be brought together in the translation of symbols, cultural moments, and codes throughout the walima ceremony, which can be understood by the structure of their consciousness.

In addition, Hindus often make strategic efforts to involve themselves in social networks and groups at inter-religious forums and other communities in Sidoarjo. Of significance are the Forum for Religious Harmony (FKUB), the Indonesian Community Sports and Recreation Federation (FORMI), involvement in Gus Durian's activities, and

\footnotetext{
${ }^{18}$ For comparison see further at https://kebudayaan.kemdikbud.go.id/bpcbbali/bhinneka-tunggal-

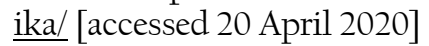

${ }^{19}$ Clifford Geertz, supra note 2.

${ }^{20}$ Ibid at 7 .

${ }^{21}$ Andrew Beatty, Variasi Agama di Jawa: Suatu Pendekatan Antropologi (Jakarta: PT Grafindo Persada, 2001).

${ }^{22}$ Ibid.
} 
Semalam Nusantara (Ethnic Community in Sidoarjo) as well as Hindu involvement through the Indonesian Community Sports and Recreation Forum (FORMI).

Hindus display their cultural identity in certain activities, for example through the traditional Balinese art of baleganjur. Baleganjur is a group of lines playing the gamelan. In an event commemorating the Anniversary of Sidoarjo Regency, Hindu youths performed baleganjur on behalf of FORMI. This opportunity really attracted the enthusiasm of the community who watched a series of parades and enjoyed the lively sound of gongs and gamelan as well as the ogoh-ogoh carried by Hindu youth in Sidoarjo.

Hindus participation in social activities in Sidoarjo is a form of deep networking between religious communities and groups. Hindus further develop their identities through the formation of an "intermediate space" within which they are able to meet various entities and engage in dialogue. These group networks operate as a forum for selfexploration in the community and government legitimacy.

\section{B. Formation in the Military Structure and Educational Institutions}

Another way Hindus involved themselves in the formation of the third space in Sidoarjo was through the police structure, supervising the Tawur Agung Kesanga Ceremony at Pura Margo Wening in Krembung. The involvement of the state apparatus from the police, navy, and muspika can be assumed as an effort to strengthen identity by building relationships between them. Apart from building social relations, this involvement is also significant in terms of disciplinary forms power, articulated through supervision and security. The police requested help to make ogoh-ogoh during the Bhayangkara Day celebration. In Sidoarjo, there is a Sunday school called pasraman for children and adolescents receiving Hindu religious teachings, making up for the lack of Hindu material taught in schools.

Hindu teaching only occurs in schools if there are at least 15 Hindu students. For example, SMA l (Senior High School 1) has eight Hindu students, the next closest school, for example SMA 2 (Senior High School 2), has seven. The two senior high schools must work together to find a teacher to take these classes either at SMA 1 or SMA 2.

This system becomes problematic when there are low numbers of Hindu students in a particular area, making it difficult to combine classes. In these circumstances, Hindu children must seek religious education outside of their schools in pasraman. As the number of students in pasraman increased, classrooms expanded and teachers were able to give grades based on the Minimum Completion Criteria (KKM) for each school.

Educational institutions are limited in quantity due to the number of students and regulations bringing teachers in to schools. Pasraman is a strategy because that integrates local Sunday schools and formal institutions, combining both religion and education. On this basis, the government cannot directly monitor the teaching and learning process in these institutions by establishing a standard curriculum in Pasraman.

\section{Formation Through Ogoh-ogoh}


Hindus seem to reinforce their cultural identity through the implementation of the tawur agung kesanga ceremony. The term tawur, nawur means to pay, or return. This serves as a thank you to nature for everything it has provided in the year. Kesanga means the ninth, indicating that it falls on the month of Tilem Sasih Kesanga, while Nyepi is entering the lst year of Saka Sasih Kedasa (10th). During the tawur agung ceremony, the mecaru ritual makes offerings to bhuta kala. Following this, pengerupukan is intended to harmonize the natural conditions with the burning of ogoh-ogoh by burning off the evil qualities of butha kala. During the ceremony the philosophical concept of Tri Hita Karana, taken from Hindu teachings, is manifested in cultural activities, representing an affirmation of the Tri Hita Karana philosophy.

Tri Hita Karana is voiced by an elite figure during the ceremony, articulating the Hindu philosophy and discourse to the Sidoarjo media. Questioning about the form of the ceremony is integrated into 3 frameworks of Hindu life: (i) tatwa, meaning aqidah or philosophy; (ii) sila, meaning behavior or moral order; (iii) ceremony. An analogy of how the life and behavior of Hindus through the egg symbol reflects how the patterns of commitment and awareness of each Hindu subject has become an integral unit unit. ${ }^{23}$ By linking the ceremony to other major discourses, namely Islam, the elite can bring the trauma of history and identity narratives to the media. This shows the context brought by Hindu subjects in Sidoarjo to cultural events, namely the affirmation of cultural identity. This cultural event allows interaction between a broad range of discourses among the subjects. Drawing on Foucault's theory, we can see how the subjects could be seen not as a conscious and autonomous being but rather as a discourse locus that is spread out, decentralized, and diverse. ${ }^{24}$

The burning of ogoh-ogoh indicates the closing of the Tawur Agung Kasanga Ceremony. Ogoh-ogoh is a symbol of bhuta kala, it is magical and symbolic, representing evil things. It represents a narrative of how nature is interpreted as complex space through the mapping of binary concepts such as great (big) and alit (small), and Sekala (real) and Niskala (virtual). Ogoh-ogoh was previously paraded at an intersection. The large crossroad is the peak location for the ogoh-ogoh procession because it represents the meeting point of currents in all directions; east, west, north, and south are representations of each god. Representation of worship during the mecaru ceremony reflects this. A series of ceremonies can be both mystical and contextualized in cultural situations. The symbols implied in the ogoh-ogoh, or the ceremonial ritual of Tawur Agung Kesanga, demonstrate cultural identity.

In today's technological era, masses compete to capture and document this moment via cellphone cameras, fighting for space to get closer to the creepy ogoh-ogoh figures. The temple at which the ceremony is held is located far from the heart of Sidoarjo. Through the use of media, this cultural event, and Sidoarjo itself, are not truly singular. Rather, their complexity that can still be built in its own way through the cultural events

${ }^{23} \mathrm{Ibid}$ at 323.

${ }^{24}$ Madan Sarup, Posstrukturalisme dan Posmodernisme, Sebuah Pengantar Klasik $\quad$ (Yogyakarta: Penerbit Jendela, 2003) at 127-128. 
they display. These ceremonies and displays introduce non-Hindus to the Hindu identity. Ogoh-ogoh is made up of materials including paper, sterofom, and rubber. Ogohogoh is not identified in the Javanese and Sanskrit dictionaries, but according to the Balinese dictionary, ogoh-ogoh means a kind of statue made of bamboo and paper in the form of Buthakala or giant. ${ }^{25}$

In 2017 the Youth of Karang Taruna Hindu Sidoarjo made ogoh-ogoh independently for the first time. The process began in early January, involving artists who were imported from Bali. One of the ogoh-ogoh is named Leak NKRI and was made as scary as possible as a representation of giant butha. For them, the Leak NKRI was made deliberately to symbolise of the rulers and leaders who oppress the people. The creation was giant to demonstrate that they consider it a bully.

Leak NKRI also participated in enlivening the Sidoarjo Regency Anniversary with the theme Pari Temple. The event involved various performances by official agencies, communities, and representatives from sub-districts in Sidoarjo. Through the sacred ceremony of Agung Kesanga, the creativity of Hindu youth groups in the regency anniversary event signifies the creation of a 'third space' to the mass base. With the interest of the media and the masses who witness the procession, ogoh-ogoh is interpreted and created into a powerful form of voice and identity. This identity is represented through ideas, strategies, and creative power, demonstrating how Hindus in Sidoarjo are adapting themselves to survive in a changing context.

The identity formation flowed along with the unstoppable third spatial motion. The third space of the Bhabha thus makes an important contribution to understanding cultural encounters. Implicit Bhabha argues that cultural identity is not an innate form of identity that is produced in a vacuum and given at birth. Cultural identity is not a predestined. It cannot be reduced, nor can the characteristic of ahistorical culture that determines cultural convection. ${ }^{26}$ Thus, cultural codes continue to change through the third space, reshaping the Hindu Sidoarjo subject and identity.

Genealogy, ritual practice, and social structure support the construction of identity. Hindu identity in Sidoarjo relies on affirmation from the Hindu subject itself. There is an alternative space within which marginalised or minority identities can enter under dominant discourse, where they can voice and articulate their own identity and its representation. Thus, the experience of the Hindu subject, individually translates Hindu identity in Sidoarjo narrative as a cultural identity in the spatial city of Sidoarjo.

\section{CONCLUSION}

Historical records in Sidoarjo fail to document the presence of Hindus in its community. Instead, the discourse demonstrates a periodization of Hinduism, packaged as artifacts without understanding of Hindu subjectivity and identity. In this context, boundaries were formed between Hindus and the community that was struggling for its own history 2017).

${ }^{25}$ M S Al Fattah, Tradisi Upacara Ogoh-ogoh (Surabaya: Departemen Antropologi Universitas Airlangga,

${ }^{26}$ Sutrisno \& Hendar Putranto, Hermeneutika Pascakolonial Soal Identitas (Yogyakarta: Kanisius, 2008). 
and local identity, discouraging the Sidoarjo local government's version of history. Hindu culture interprets and articulates its own identities which can be understood in terms of three categories of Sidoarjo Hindus: (i) Hinduism from Sidoarjo; (ii) Hinduism from outside Sidoarjo; (iii) and Hinduism from Bali. These categories merged and collaborated in the inauguration of the pedanda from Sidoarjo, in the form of temple building and a sector platform to connect the bonds between Hindus in Sidoarjo. This indicated the plurality of Hindus in Sidoarjo formed by their shared cultural spaces.

\section{ACKNOWLEDGEMENTS}

None

\section{COMPETING INTERESTS}

None

\section{REFERENCES}

Andrew Beatty, Variasi Agama di Jawa: Suatu Pendekatan Antropologi (Jakarta: PT Grafindo Persada, 2001).

Clifford Geertz, Tafsir Kebudayaan (Yogyakarta: Kanisius, 1992).

Hammersley, Martin \& Paul Atkinson, Ethnography Principles in Practice, third ed (New York: Taylor \& Francis e-Library, 2007).

Homi K Bhabha, The Location of Culture (London: Rouledge, 1994).

M Foucault, Arkeologi Pengetahuan (Yogyakarta: IRCiSoD, 2012).

M S Al Fattah, Tradisi Upacara Ogoh-ogoh (Surabaya: Departemen Antropologi Universitas Airlangga, 2017).

Madan Sarup, Posstrukturalisme dan Posmodernisme, Sebuah Pengantar Klasik (Yogyakarta: Penerbit Jendela, 2003).

Martin Lukitto Sinaga, IdentitasPoskolonial “Gereja Suku” dalam Masyarakat Sipil (Yogyakarta: LkiS, 2004).

Michel Picard, Bali: Pariwisata Budaya dan Budaya Pariwisata (Jakarta: kepustakaan Populer Gramedia, 2006).

Minako Sakai, Kacang Tidak Lupa Kulitnya: Identitas Gumay, Islam, dan Merantau di Sumatera Selatan (Jakarta: Yayasan Pustaka Obor Indonesia, 2017).

Richard King, Agama, Orientalisme, dan Poskolonialisme (Yogyakarta: Qalam, 2001).

Sutrisno \& Hendar Putranto, Hermeneutika Pascakolonial Soal Identitas (Yogyakarta: Kanisius, 2008).

Thomas A Reuters, Custodians of The Sacred Mountains: Budaya dan Masyarakat di Pegunungan Bali (Jakarta: Yayasan Obor Indonesia, 2005).

Tim Penelusuran Sejarah Sidoarjo, Jejak Sidoarjo dari Jenggala ke Suriname (Sidoarjo: Ikatan Alumni Pramong Praja Sidoarjo, 2006).

Siswanto, "Identifikasi penggunaan Lahan Berdasarkan Sumber Prasasti Abad Ke-ll Masehi di Jawa Timur" (2015) Purbawidya: Jurnal Penelitian dan Pengembangan Arkeologi.

Hery Prasetyo, Development And Uneven Development (Does Democratization Work?) (2012). 